\title{
AKTIVITAS ANTIOKSIDAN EKSTRAK dan FRAKSI KULIT BATANG TRENGGULI (Cassia fistula L) DENGAN METODE DPPH
}

\author{
Aji Najihudin, Anis Chaerunisaa, Anas Subarnas \\ Fakultas Farmasi Universitas Padjadjaran, Sumedang, Jawa Barat, Indonesia
}

\begin{abstract}
Abstrak
Kulit batang trengguli (Cassia fistula $\mathrm{L}$ ) mengandung senyawa yang bersifat antioksidan yang dapat ditentukan dengan metode peredaman radikal bebas 1,1-Difenil-2- Pikrilhidrazil (DPPH). Penelitian ini dilakukan untuk mengetahui adanya peredaman radikal bebas DPPH oleh ekstrak etanol kulit batang trengguli (EEKBT), fraksi Etil asetat (FEAKBT), fraksi nHeksan (FnHKBT), fraksi air (FAKBT) dan vitamin $\mathrm{C}$ sebagai pembanding. Identifikasi golongan senyawa dilakukan dengan penapisan fitokimia. Fraksinasi dilakukan dengan metode ekstraksi cair-cair dengan tingkat kepolaran yang berbeda. Aktivitas antioksidan dilakukan dengan peredaman warna radikal bebas DPPH menggunakan spektrofotometri UVVis. Penelitian menunjukkan bahwa Fraksi etil asetat memiliki aktivitas antioksidan paling baik dengan nilai $\mathrm{IC}_{50} 3,980 \mu \mathrm{g} / \mathrm{ml}$ dibandingkan vitamin $\mathrm{C} \quad 4,716 \mu \mathrm{g} / \mathrm{ml}$. Sedangkan nilai $\mathrm{IC}_{50}$ ekstrak etanaol, fraksi n-heksan, fraksi air adalah 10,613 $\mu \mathrm{g} / \mathrm{ml}, 38,904 \mu \mathrm{g} / \mathrm{ml}$ dan 7,636 $\mu \mathrm{g} / \mathrm{ml}$ terhadap peredaman warna DPPH.
\end{abstract}

Kata kunci: Antioksidan, Cassia fistula, Fraksinasi, metode DPPH

\section{ANTIOXIDANT ACTIVITY IN THE EXTRACT ETHANOL AND FRACTION TRENGGULI BARK (Cassia fistula L) BY DPPH METHOD}

\begin{abstract}
The bark Trengguli (Cassia fistula L) containing compounds are antioxidants which can be determined by the method of reduction of free radicals 1,1-Diphenyl-2- picrylhydrazyl (DPPH). This study was conducted to investigate the reduction of free radicals DPPH by Trengguli stem bark ethanol extract (EEKBT), Ethyl acetate fraction (FEAKBT), the fraction $\mathrm{n}$-Hexane (FnHKBT), the water fraction (FAKBT) and vitamin $\mathrm{C}$ as a standard. The identification of the class of compounds was performed by phytochemical screening. Fractionation is done by liquid-liquid extraction method with a different degree of polarity. Reduction of antioxidant activity with DPPH free radical colors using UV-Vis spectrophotometry. Research shows that ethyl acetate fraction has the best antioxidant activity with IC50 value $3,980 \mu \mathrm{g} / \mathrm{ml}$ compared to vitamin c with IC50 value $4,716 \mu \mathrm{g} / \mathrm{ml}$. While the IC50 value of ethanol extract, n-hexane fraction, the fraction of water is $10.613 \mathrm{~g} / \mathrm{ml}$, $38.904 \mathrm{ug} / \mathrm{ml}$ and $7.636 \mathrm{mg} / \mathrm{mL}$ against DPPH color reduction.
\end{abstract}

Keywords: Antioxidant, Cassia fistula, Fraction, DPPH Method 


\section{Pendahuluan}

Radikal bebas merupakan suatu senyawa atau molekul yang memiliki satu atau lebih elektron tidak berpasangan meyebabkan senyawa tersebut sangat reaktif mencari pasangan, dengan mengikat elektron molekul yang berada di sekitarnya. Radikal bebas dapat berasal dari dalam tubuh sebagai bagian dari hasil proses metabolisme. Sedangkan radikal bebas yang bersumber dari luar tubuh dapat disebabkan oleh faktor lingkungan, termasuk kebiasaan merokok, penggunaan pestisida pada makanan, polusi dan radiasi (Mbaoji et al., 2016).

Antioksidan merupakan senyawa pemberi elektron (donor elektron) yang dapat menghambat reaksi oksidasi, dengan mengikat radikal bebas dan molekul yang sangat reaktif. Antioksidan berperan menangkal radikal bebas dalam tubuh sehingga dapat melawan kerusakan oksidatif juga menghambat proses oksidasi lemak/minyak sehingga mempunyai fungsi sebagai pengawet (Brand-Williams, Cuvelier, \& Berset, 1995).

Antioksidan memiliki kemampuan untuk menetralisir radikal bebas tanpa menjadi radikal bebas itu sendiri (Widyawati, 2016). Ketika antioksidan menetralkan radikal bebas dengan menerima atau menyumbangkan elektron, mereka tidak akan berubah menjadi radikal bebas dan tetap stabil. Antioksidan banyak terdapat pada sayuran, buah-buahan dan tanaman obat (Fatima, Abderrahmane, Seddik, \& Lekhmici, 2016).

Penggunaan bahan alam sebagai obat tradisional tidaklah cukup hanya berdasarkan pengalaman yang diwariskan secara turun-temurun, akan tetapi tumbuhan obat yang digunakan perlu dibuktikan secara ilmiah. Tumbuhan obat telah diketahui mengandung zat aktif yang dapat berkhasiat untuk penyembuhan penyakit. Berbagai penelitian telah dilakuakan untuk melihat aktivitas farmakologi dan kandungan kimia dari bahan alam. Salah satu bahan alam yang telah dilaporkan memiliki beberapa aktivitas farmakologi adalah trengguli (Cassia fistula L) (Jothy, Zuraini, \& Sasidharan, 2011).

Ekstrak biji trengguli memiliki aktivitas antioksidan dengan menghambat DPPH (Bhalodia et al., 2011). Ekstrak biji methanol trengguli memiliki aktivitas antitumor (Gupta et al., 2000) dan ekstrak bunga trengguli menunjukan aktivitas antibakteri terhadap mikroorganisme gram positif dan memiliki aktivitas antifungi terhadap Trichophyton mentagrophytes dan Epidermophyton floccosum (Duraipandiyan \& Ignacimuthu, 2007). Selain itu, senyawa antraquinon dari bunga trengguli memiliki sitotoksisitas terhadap sel kanker kolon manusia, COLO 320 DM (Duraipandiyan \& Ignacimuthu, 2007).

Berbagai penelitian yang telah dilakukan menunjukan berbagai aktivitas farmakologi dari berbagai bagian tanaman trengguli. Penelitian ini dimaksudkan untuk mengetahui potensi aktivitas antioksidan pada ekstrak dan fraksi $n$ Heksan, etil asetat dan air dari kulit batang trengguli dengan metode peredaman radikal bebas DPPH.

\section{Metode}

\section{Bahan}

Bahan tumbuhan yang digunakan dalam penelitian ini adalah kulit batang trengguli (Cassia fistula L) yang diambil Balai tanaman Obat Tradisonal (BALITRO) Manoko Lembang Kab Bandung Jawa Barat. Bahan kimia yang digunakan pada penelitian ini diantaranya yaitu etanol $70 \%$, etanol $96 \%$ pa, DPPH (2,2-difenil-1-pikril-hidrazil), vitamin $\mathrm{C}, n$-heksan, etil asetat, aquadest, kloroform, metanol, pereaksi dragendorf, pereaksi mayer, pereaksi besi (III) klorida, pereaksi kalium hidroksida, asam klorida encer, $\mathrm{HCl} 2 \mathrm{~N}$, gelatin $1 \%, \mathrm{KOH} 5 \%$, iso amil alkohol, $\mathrm{H}_{2} \mathrm{SO}_{4}, \mathrm{FeCl}_{3} 1 \%$, asam asetat $0,7 \%$. 
Alat

Peralatan yang digunakan adalah batang pegaduk, botol semprot, gelas ukur, maserator, neraca analitik, vial $20 \mathrm{ml}$, vial $100 \mathrm{ml}$, pipet, corong, labu ukur $10 \mathrm{ml}$, labu ukur $100 \mathrm{ml}$, rotary evaporator, tabung reaksi, beaker glass, bejana kromatografi, pelat KLT silika gel GF 254, lampu UV $254 \mathrm{~nm}$ dan $366 \mathrm{~nm}$, spektrofotometri dan kuvet, stopwach, dan alat laboratorium yang mendukung.

\section{Pengumpulan Bahan dan Determinasi Tumbuhan}

Bahan yang digunakan yaitu simplisia kulit batang tumbuhan trengguli dari spesies Cassia fistula L. yang diperoleh dari perkebunan Manoko, Lembang, Bandung. Determinasi tumbuhan dilakukan pada Laboratorium Taksonomi, Jurusan Biologi, Fakultas MIPA UNPAD.

\section{Ekstraksi Simplisia}

Ekstraksi simplisia kulit batang tumbuhan trengguli dilakukan dengan cara maserasi dengan pelarut etanol 70\% selama 3 kali 24 jam. Ekstrak cair dipekatkan dengan rotary evaporator pada suhu $60^{\circ} \mathrm{C}$ kemudian di uapkan diatas penangas air dengan suhu $40^{\circ} \mathrm{C}$ sehingga diperoleh berat ekstrak yang konstan. Rendemen ekstrak dapat dihitung dengan rumus:

Rendemen ekstrak (\%) =

$$
\frac{\text { massaekstrak }}{\text { massasimplisia }} \times 100 \%
$$

Selanjutnya dilakukan pemeriksaan organoleptik ekstrak yang terdiri dari bentuk, warna, bau, dan rasa ekstrak.

\section{Fraksinasi Ekstrak}

Fraksinasi ekstrak dilakukan secara partisi dengan menggunakan campuran dua pelarut yang memiliki kepolaran yang berbeda. Campuran pelarut pertama adalah campuran n-heksan : air dan yang kedua adalah campuran etil asetat : air. Pertama. Ekstak etanol dengan berat tertentu dilarutkan dalam air dengan volume tertentu sehingga ekstrak terlarut semuanya, kemudian n-heksan dengan volume tertentu ditambahkan untuk melarutkan ekstrak yang terlarut dalam pelarut non polar. Campuran tersebut dimasukkan kedalam corong pisah dan dikocok kuat-kuat hingga diperoleh lapisan air dan lapisan n-heksan, kedua lapisan kemudian dipisahkan. Kedalam lapisan air, selanjutnya ditambahkan etil asetat dan campuran tersebut dikocok kuat-kuat sehingga diperoleh lapisan air dan lapisan etil asetat, dan kedua lapisan tersebut dipisahkan. Lapisan n-heksan, lapisan air dan lapisan etil asetat kemudian diuapkan dalam rotary evaporator hingga diperoleh fraksi n-heksan, fraksi etil asetat dan fraksi air (Hikmah, 2012).

\section{Pola Kromatogram Lapis Tipis}

Kromatografi lapis tipis dilakukan untuk mengetahui kandungan senyawa kimia di dalam ekstrak. Dalam analisis kromatografi lapis tipis digunakan fase diam yaitu pelat silika gel GF 254 dan fase gerak yaitu kombinasi pelarut toluene, etil asetat, dan asam format dengan perbandingan 5:4:1. Ekstrak dilarutkan terlebih dahulu dalam etanol lalu ditotolkan pada pelat silika gel ukuran $10 \mathrm{~cm}$ x 1,0 cm dan dimasukkan ke dalam bejana kromatografi yang sebelumnya telah dijenuhkan dengan cairan pengembang. Proses kromatografi dihentikan ketika cairan pengembang mencapai garis akhir. Pola kromatogram diamati pada sinar tampak di bawah lampu UV 254 dan 366 nm, kemudian dihitung nilai $\mathrm{Rf}$. 


\section{Uji Pendahuluan Aktivitas Antioksidan Ekstrak dan Fraksi kulit Batang Trengguli}

\section{Penyiapan Sampel}

Ekstrak etanol sebanyak 1\% dibuat larutan stok dengan konsentrasi 1000 ppm sehingga diperoleh konsentrasi $0,1 \%$. Larutan stok $1000 \mathrm{ppm}$ dibuat larutan standar 2, 4, 6, 8, 10, 12 ppm.

\section{Penyiapan Larutan Pembanding}

Vitamin C sebanyak 1\% dibuat larutan stok dengan konsentrasi 1000 ppm sehingga diperoleh konsentrasi $0,1 \%$. Larutan stok 1000 ppm dibuat larutan standar 2, 4, 6, 8, 10, $12 \mathrm{ppm}$.

\section{Pembuatan Larutan DPPH (2,2-dipenil- 1-pikril-hidrazil)}

Kristal DPPH dilarutkan dalam etanol pada konsentrasi $0,01 \% \mathrm{~b} / \mathrm{v}$ sebanyak 100 $\mathrm{mL}$. Larutan DPPH dijaga dalam temperatur rendah dan terlindung cahaya.

\section{Penentuan Panjang Gelombang Maksimum}

Larutan DPPH sebanyak $1 \mathrm{ml}$ diencerkan dengan etanol sampai tanda batas labu takar $5 \mathrm{~mL}$, blanko digunakan 5 $\mathrm{mL}$ etanol, diukur pada panjang gelombang 500-530 nm untuk mendapatkan absorbansi $\pm 0,2-0,8$.

\section{Penentuan $\mathrm{IC}_{50}$ dengan Metode DPPH}

Ekstrak etanol, hasil fraksi maupun vitamin $\mathrm{C}$ dari berbagai konsentrasi masing-masing diambil $1 \mathrm{~mL}$ ditambahkan $1 \mathrm{~mL}$ DPPH, lalu divorteks dan diinkubasi selama 30 menit pada suhu kamar. Ukur absorbansinya pada panjang gelombang
$515 \mathrm{~nm}$. Dilakukan pengukuran serapan DPPH sebagai blanko pada panjang gelombang yang sama. Setelah diperoleh nilai absorban hitung $\%$ perendaman dengan menggunakan peramaan(Mbaoji et al., 2016)(Zuhra, Tarigan, \& Sihotang, 2008) di bawah ini. Dari \% perendaman yang diperoleh ditentukan $\mathrm{IC}_{50}$ yaitu konsentrasi yang mampu menghambat $50 \%$ radikal bebas.

$$
\% \text { perendaman }=\frac{A b-A s}{A b} \times 100 \%
$$

Keterangan:

$\mathrm{Ab}=$ Absorban blanko $=$ nilai absorbansi DPPH

As $=$ Absorbansi sampel $=$ nilai absorbansi sampel

\section{Hasil}

Hasil determinasi tumbuhan Cassia fistula ini termasuk ke dalam Famili: Fabaceae (suku polong-polongan), Genus: Cassia, Spesies: Cassia fistula L. Ekstraksi kulit batang trengguli (1000 g) secara maserasi dengan pelarut etanol $70 \%$ menghasilkan ekstrak kental kulit batang trengguli 33,6 (rendemen 33,6\%). Hasil penapisan fitokimia ekstrak kental kulit batang dapat dilihat pada Tabel 1 .

\section{Pembahasan}

Fraksinasi ekstrak etanol kulit batang trengguli sebanyak $110 \mathrm{~g}$ dengan metode ekstraksi cair-cair menggunakan pelarut $n$ heksan, etil asetat, dan air dihasilkan data pengamatan organoleptik dan persen rendemen dari ekstrak dan seluruh fraksi. Hasil Pengamatan organoleptik dari ekstrak dan seluruh fraksi dapat dilihat pada tabel 2. Hasil fraksinasi bobot dan persen rendemen dari ekstrak dan seluruh fraksi dapat dilihat pada tabel 3 . 
Tabel 1 Hasil Penapisan Fitokimia Ekstrak Etanol Kulit Batang Trengguli

\begin{tabular}{cc}
\hline Golongan Senyawa & Hasil Pengujian \\
\hline Alkaloida & - \\
Tanin & - \\
Polifenol & + \\
Saponin & + \\
Flavonoid & + \\
Monoterpenoid dan seskuiterpenoid & $(+/+)$ \\
Steroid & - \\
Triterpenoid & - \\
Kuinon & +
\end{tabular}

Keterangan : terdeteksi (+); tidak terdeteksi (-).

Tabel 2 Hasil Pengamatan Organoleptik dari Ekstrak dan Seluruh Fraksi

\begin{tabular}{ccccc}
\hline \multirow{2}{*}{ Parameter } & \multicolumn{4}{c}{ Komponen Ekstrak dan Fraksi } \\
\cline { 2 - 5 } & Ekstrak Etanol & n-Heksan & Etil Asetat & Air \\
\hline Bentuk & Cairan Kental & Cairan Encer & Cairan Kental & serbuk kristal \\
Bau & Khas Trengguli & Khas Trengguli & Khas Trengguli & Khas Trengguli \\
Warna & Coklat tua & Coklat & Coklat muda & Coklat \\
Rasa & Pahit & Pahit & Pahit & Pahit \\
\hline
\end{tabular}

Tabel 3 Hasil Fraksinasi Bobot dan Persen Rendemen dari Ekstrak Etanol Kulit Batang Trengguli

\begin{tabular}{ccc}
\hline Fraksi & $\begin{array}{c}\text { Bobot Fraksi } \\
(\mathrm{g})\end{array}$ & $\begin{array}{c}\text { Rendemen } \\
(\%)\end{array}$ \\
\hline n-Heksan & 4,25 & 3,86 \\
Etil Asetat & 40,57 & 36,88 \\
Air & 16,8 & 15,27 \\
\hline
\end{tabular}

Kromatografi lapis tipis (KLT) dilakukan dengan menggunakan lempeng silika gel GF 254, dengan pengembang toluene, etil asetat, dan asam format dengan perbandingan 5:4:1. Hasil KLT dilihat pada sinar tampak, UV $254 \mathrm{~nm}$ dan UV $366 \mathrm{~nm}$ Hasil KLT dapat dilihat pada Tabel 4.

Hasil Uji Aktivitas Antioksidan: Pemeriksaan aktivitas antiradikal bebas DPPH secara spektrofotometri dilakukan dengan mereaksikan sampel dengan larutan DPPH. DPPH merupakan radikal sintetik yang larut dalam pelarut polar seperti metanol dan etanol. DPPH merupakan radikal yang stabil yang dapat diukur intensitasnya pada panjang gelombang $515 \mathrm{~nm}$ (Brand-Williams et al., 1995)(Thaipong, et al., 2006).

Pengukuran absorbansi sampel dilakukan pada konsentrasi 2 ppm, 4 ppm, 6 ppm, 8 ppm, dan 12 ppm. Uji daya antioksidan dengan metode DPPH (2,2difenil-1-pikril hidrazil) dimaksudkan untuk menguatkan aktivitas suatu senyawa uji (ekstrak etanol dan seluruh fraksi kulit batang trengguli) sebagai antioksidan karena sebagaimana diketahui daya antioksidan dapat dilakukan dengan berbagai macam metode (Rohman, 2006). Hasil pengujian aktivitas antioksidan ekstrak etanol $70 \%$, fraksi n-heksan, etil 
asetat, dan air kulit batang trengguli dapat dilihat pada Tabel 5-8.

Sebagai pembanding digunakan vitamin $\mathrm{C}$ yang sudah diketahui sebagai antioksidan. Hasil pengukuran daya Antioksidan vitamin $\mathrm{C}$ dengan metode
DPPH pada Tabel 8. Hubungan antara konsentrasi antioksidan ekstrak etanol 70\%, fraksi n-heksan, etil asetat, dan air kulit batang trengguli terhadap persen inhibisi dapat dilihat pada gambar 1 .

Tabel 4 Hasil Pengujian KLT Ekstrak Etanol, Tablet Ekstrak, Fraksi Etil Asetat Dan Tablet Fraksi Etil Asetat Kulit Batang Trengguli

\begin{tabular}{clccc}
\hline \multirow{2}{*}{ Jenis } & \multicolumn{1}{c}{ Bercak } & Sinar Tampak & $\mathrm{UV}_{366}$ & $\mathrm{UV}_{254}$ \\
\hline \multirow{2}{*}{ Ekstrak } & 1 (biru) & - & 0,508 & - \\
& 2 (merah) & - & 0,678 & - \\
& 3 (hijau) & - & 0,763 & - \\
\hline \multirow{2}{*}{ Fraksi } & 1 (biru) & - & 0,508 & - \\
& 2 (jingga) & - & 0,712 & - \\
\hline
\end{tabular}

Tabel 5 Hasil Pengujian Aktivitas Antioksidan Ekstrak etanol 70\% Kulit Batang Trengguli

\begin{tabular}{ccccc}
\hline $\begin{array}{c}\text { Konsentrasi } \\
(\mathrm{ppm})\end{array}$ & Absorbansi* & $\begin{array}{c}\% \\
\text { inhibisi* }\end{array}$ & regresi & IC 50 \\
\hline 2 & 0,738 & 19,344 & & \\
4 & 0,713 & 22,077 & $\mathrm{y}=$ & \\
6 & 0,603 & 34,098 & $3,761 \mathrm{x}$ & 10,613 \\
8 & 0,539 & 41,093 & + & $\mu \mathrm{g} / \mathrm{ml}$ \\
10 & 0,503 & 45,027 & 10,084 & \\
12 & 0,395 & 56,831 & & \\
\hline * & & \\
\hline
\end{tabular}

* Hasil 3 kali pengukuran ; * Absorbansi kontrol 0,915

Tabel 6 Hasil Pengujian Aktivitas Antioksidan Fraksi n-Heksan Kulit Batang Trengguli

\begin{tabular}{ccccc}
\hline $\begin{array}{c}\text { Konsentrasi } \\
(\mathrm{ppm})\end{array}$ & Absorbansi* & $\begin{array}{c}\% \\
\text { inhibisi* }\end{array}$ & regresi & IC 50 \\
\hline 2 & 0,758 & 17,158 & & \\
4 & 0,737 & 19,454 & & \\
6 & 0,729 & 20,328 & $\mathrm{y}=$ & 38,904 \\
8 & 0,7 & 23,497 & $15,57 \mathrm{x}$ & $\mu \mathrm{g} / \mathrm{ml}$ \\
10 & 0,696 & 23,934 & & \\
12 & 0,675 & 26,230 & & \\
\hline
\end{tabular}

* Hasil 3 kali pengukuran ; * Absorbansi kontrol 0,915 
Tabel 7 Hasil Pengujian Aktivitas Antioksidan Fraksi Etil asetat Kulit Batang Trengguli

\begin{tabular}{ccccc}
\hline $\begin{array}{c}\text { Konsentrasi } \\
(\mathrm{ppm})\end{array}$ & Absorbansi* & $\begin{array}{c}\% \\
\text { inhibisi* }\end{array}$ & regresi & IC 50 \\
\hline 2 & 0,549 & 40,000 & & \\
4 & 0,465 & 49,180 & & \\
6 & 0,368 & 59,781 & $\mathrm{y}=$ & 3,980 \\
8 & 0,241 & 73,661 & $30,788 \mathrm{x}+$ & $\mu \mathrm{g} / \mathrm{ml}$ \\
10 & 0,22 & 75,956 & & \\
12 & 0,108 & 88,197 & & \\
\hline
\end{tabular}

* Hasil 3 kali pengukuran ; * Absorbansi kontrol 0,915

Tabel 8 Hasil Pengujian Aktivitas Antioksidan Fraksi Air Kulit Batang Trengguli

\begin{tabular}{ccccc}
\hline $\begin{array}{c}\text { Konsentrasi } \\
(\mathrm{ppm})\end{array}$ & Absorbansi & $\begin{array}{c}\% \\
\text { inhibisi* }\end{array}$ & regresi & IC 50 \\
\hline 2 & 0,339 & 38,475 & & \\
4 & 0,333 & 39,564 & & \\
6 & 0,312 & 43,376 & $\mathrm{y}=$ & 7,64 \\
8 & 0,273 & 50,454 & $+3201 \mathrm{x}$ & $\mu \mathrm{g} / \mathrm{ml}$ \\
10 & 0,242 & 56,080 & & \\
12 & 0,207 & 62,432 & & \\
\hline
\end{tabular}

* Hasil 3 kali pengukuran ; * Absorbansi kontrol 0,915

Tabel 9 Hasil Pengujian Aktivitas Antioksidan Vitamin C

\begin{tabular}{ccccc}
\hline $\begin{array}{c}\text { Konsentrasi } \\
(\mathrm{ppm})\end{array}$ & Absorbansi* & $\begin{array}{c}\% \\
\text { inhibisi* }\end{array}$ & regresi & IC 50 \\
\hline 2 & 0,625 & 31,69 & & \\
4 & 0,548 & 40,11 & & \\
6 & 0,301 & 67,10 & $\mathrm{y}=$ & 4,716 \\
8 & 0,259 & 71,69 & 21,151 & $\mu \mathrm{g} / \mathrm{ml}$ \\
10 & 0,166 & 81,86 & & \\
12 & 0,079 & 91,37 & & \\
$*$ Hasil 3 kali pengukuran * Absorbansi kontrol 0,915 &
\end{tabular}

Tabel 10 Nilai $\mathrm{IC}_{50}$ Pengujian Aktivitas Antioksidan Kontrol, Ekstrak dan Fraksi Kulit Batang Trengguli

\begin{tabular}{ccr}
\hline No & Sample & \multicolumn{1}{c}{$\begin{array}{c}\text { IC50 } \\
(\mu \mathrm{g} / \mathrm{ml})\end{array}$} \\
\hline 1 & Vitamin C & 4,716 \\
2 & EEKBT & 10,613 \\
3 & FnHKBT & 38,904 \\
4 & FEAKBT & 3,980 \\
5 & FWKBT & 7,636 \\
\hline
\end{tabular}

Tabel 10 menunjukkan bahwa fraksi etil asetat mempunyai daya antioksidan dengan metode DPPH dengan nilai IC50 sebesar 3,980 $\mu \mathrm{g} / \mathrm{ml}$. IC50 merupakan konsentrasi kulit batang trengguli yang mampu memberikan persen penangkapan 
radikal sebanyak $50 \%$ dibanding kontrol melalui suatu persamaan garis regresi linier, semakin kecil nilai IC50 berarti semakin kuat daya antioksidannya. Fraksi Etil asetat memiliki aktivitas yang lebih baik diantara kontrol, ekstrak dan fraksi lain dengan nilai $\mathrm{IC}_{50} \quad 3,980 \quad \mu \mathrm{g} / \mathrm{ml}$ dibandingkan dengan vitamin $\mathrm{C}$ dengan nilai $\mathrm{IC}_{50} 4,716 \mu \mathrm{g} / \mathrm{ml}$.

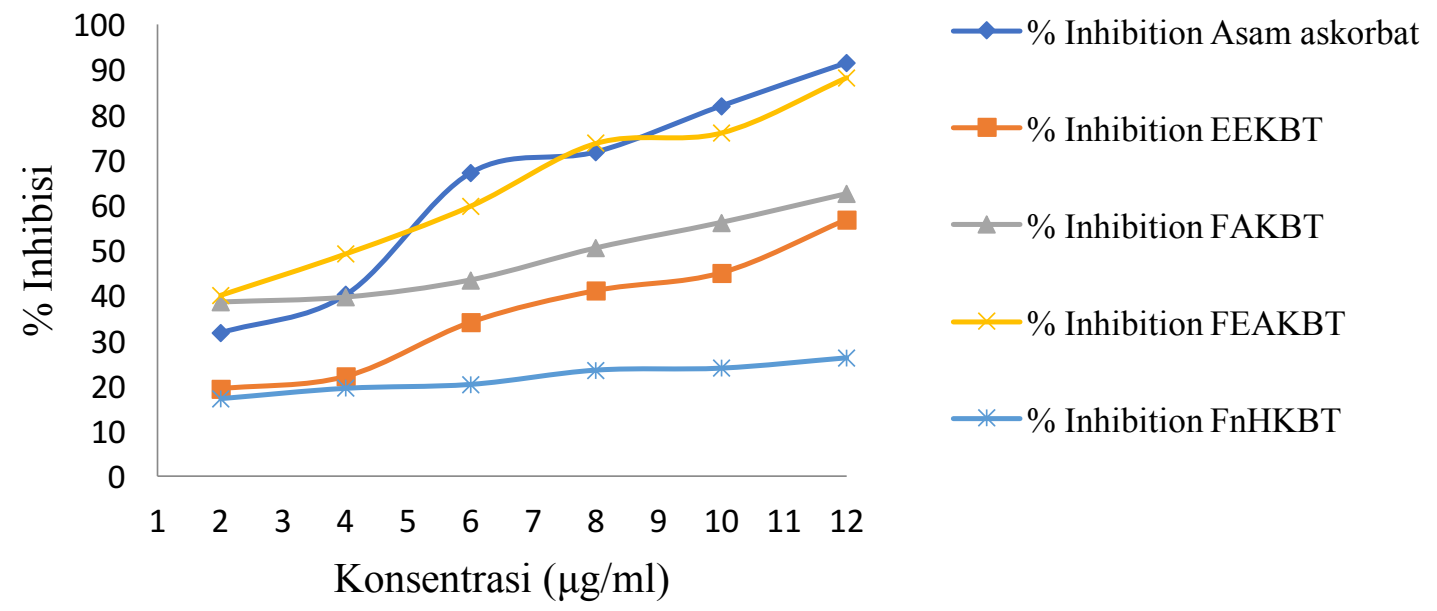

Gambar 1 Hubungan Antara Konsentrasi Antioksidan Ekstrak Etanol 70\% dan Fraksi Kulit Batang Trengguli terhadap Persen Inhibisi

\section{Simpulan}

Hasil penelitian menunjukkan bahwa ekstrak etanol, fraksi $n$-heksan, fraksi etil asetat, dan fraksi air kulit batang trengguli memberikan aktivitas antioksidan dengan metode DPPH. Fraksi etil asetat memiliki aktivitas antioksidan paling baik dengan nilai $\quad \mathrm{IC}_{50} \quad 3,980 \quad \mu \mathrm{g} / \mathrm{ml}$ dibandingkan vitamin $\mathrm{c}$ dengan nilai $\mathrm{IC}_{50} 4,716 \mu \mathrm{g} / \mathrm{ml}$. Sedangkan nilai $\mathrm{IC}_{50}$ ekstrak etanaol, fraksi n-heksan, fraksi air adalah 10,613 $\mu \mathrm{g} / \mathrm{ml}$, $38,904 \mu \mathrm{g} / \mathrm{ml}$ dan $7,636 \mu \mathrm{g} / \mathrm{ml}$.

\section{Daftar Pustaka}

1. Brand-Williams, W., Cuvelier, M. E., \& Berset, C. Use of a free radical method to evaluate antioxidant activity. LWT Food Science and Technology,1995; 28(1), 25-30.

2. Duraipandiyan, V., \& Ignacimuthu, S. Antibacterial and antifungal activity of Cassia fistula L .: An ethnomedicinal plant, 2007; 112, 590-594.

3. Fatima, Z., Abderrahmane, B., Seddik,
K., \& Lekhmici, A. Antioxidant Activity Assessment Of Tamus Communis L . Roots, 2016; 8(12).

4. Gupta, M., Mazumder, U. K., Rath, N., \& Mukhopadhyay, D. K. Antitumor activity of methanolic extract of Cassia fistula L . seed against Ehrlich Ascites Carcinoma, 2000; 72, 151-156.

5. Hikmah, F. dinul. Pengaruh partisi bertingkat cair-cair ekstrak etanol rimpang jahe (Zingiber officinale Rosc.) terhadap profil kandungan senyawa kimia dan aktivitas antiradikalnya. Pengaruh Partisi Bertingkat Cair-Cair Ekstrak Etanol Rimpang Jahe (Zingiber Officinale Rosc.) Terhadap Profil Kandungan Senyawa Kimia Dan Aktivitas Antiradikalnya, 2012; 1-17.

6. Jothy, S. L., Zuraini, Z., \& Sasidharan, S. Phytochemicals screening, DPPH free radical scavenging and xanthine oxidase inhibitiory activities of Cassia fistula seeds extract. Journal of Medicinal Plants Research, 2011; 5(10), 1941-1947.

7. Mbaoji, F. N., Ezike, A. C., Nworu, C. 
S., Onyeto, C. A., Nwabunike, I. A., Okoli, I. C., \& Akah, P. A. Antioxidant And Hepatoprotective Potentials Of Stemonocoleus Micranthus Harms ( Fabaceae ) Stem Bark Extract, 2016; 8(7).

8. Rohman, A. Aktivitas antioksidan, kandungan fenolik total dan kandungan flavonoid total ekstrak etil asetat buah Mengkudu serta fraksi-fraksinya, 2006; 17(3), 136-142.

9. Thaipong, K., Boonprakob, U., Crosby, K., Cisneros-Zevallos, L., \& Hawkins Byrne, D. Comparison of ABTS, DPPH, FRAP, and ORAC assays for estimating antioxidant activity from guava fruit extracts. Journal of Food Composition and Analysis, 2006; 19(67), 669-675.

10. Widyawati, P. S. R. I. Determination Of Antioxidant Capacity In Pluchea Indica Less Leaves Extract And Its Fractions, 2016; 8(9).

11. Zuhra, C. F., Tarigan, J. B., \& Sihotang, H. Aktivitas Antioksidan Senyawa Flavonoid Dari Daun Katuk (Sauropus androgunus (L) Merr .), 2008; 3(1), 10-13. 